\title{
Mesanthemum tuberosum Lecomte resurrected from $M$. prescottianum (Bong.) Körn. (Eriocaulaceae), variation and lectotypification
}

\author{
Sylvia M. Phillips ${ }^{1}$, Fatoumata Fofana ${ }^{2}$ \& Martin Cheek $^{1}$ (I)
}

Summary. Mesanthemum prescottianum is a West African species occurring in the uplands extending from Guinea to Ivory Coast. Variation within the species is discussed and the synonym M. tuberosum Lecomte is raised to specific status. The conservation status of the first species is assessed using the IUCN 2012 standard as Least Concern, and the second as Vulnerable. Lectotypes are selected for both names. The type location of $M$. prescottianum, claimed to be Brazil, is shown to be an error.

Key Words. Brazil, lectotype, taxonomy, West Africa.

Mesanthemum is a genus of c. 15 species occurring in Africa, with two in Madagascar (Phillips 2011). It is relatively uniform, the majority of species being perennials from a tough rootstock or rhizome, and is more vigorous than all except the largest species of Eriocaulon in Africa. Eriocaulon is a pantropical genus with many more species in Africa than Mesanthemum. Mesanthemum lacks the fenestrate leaves found in Eriocaulon, and can also be readily distinguished from nearly all African species of that genus by its hairy leaves and scapes (Phillips 2011). An early division in keys to Mesanthemum is the easily observed character as to whether the inner involucral bracts radiate beyond the central disc of flowers, thus resembling the ray florets of a member of the Asteraceae (Jacques-Félix 1947; Meikle 1968; Phillips 2010). This character is well expressed in the West African species M. prescottianum (Bong.) Körn., where the white capitula are often described as "daisy-like". The only other species with similar daisy-like capitula is M. bennae Jacq.-Fél., also from Guinea but known only from cliffs of Mt Benna, at Kounounkan. It is easily distinguished from both $M$. prescottianum and $M$. tuberosum by its stouter habit, much broader leaves (c. $20 \mathrm{~mm}$ ), broader velutinous involucral bracts and pilose floral bracts.

A recent field trip to the Fouta Djalon upland region of Guinea (Conakry) by the third author as part of the Tropical Important Plant Areas programme (Darbyshire, continuously updated; Darbyshire et al. 2017) has resulted in a reassessment of variation in Mesanthemum prescottianum. This species is confined to uplands in the West African countries of Guinea, Sierra Leone, Liberia and Ivory Coast. It is known to be rather variable, as noted by Jacques-Félix (1947: 144), who reduced M. tuberosum Lecomte from Fouta Djalon to synonymy within $M$. prescottianum. This treatment was followed by Meikle in Flora of West Tropical Africa (1968: 64).

Mesanthemum prescottianum is a distinctive species in the field due to its conspicuous shining white "daisy" capitula with sharply acute, spreading involucral bracts. Material collected in Fouta Djalon looks different in the field, with duller, whitish capitula, narrower, obtuse involucral bracts and scapes arising from well-developed underground corms (Fig. 1), at first leading to the suspicion that that it could be an undescribed species. This population was subsequently found to match the type of $M$. tuberosum. A detailed examination of all the material in the Kew herbarium showed the Fouta Djalon material to be sufficiently distinct from $M$. prescottianum, both morphologically and in habitat preference, to merit specific status. Mesanthemum tuberosum is therefore resurrected here. As the Flora of West Tropical Africa does not include descriptions, a full description of both species is given.

This paper is part of a series of studies on African Eriocaulaceae by the first author. Recent discoveries of W African members of the family include Phillips \& van der Burgt (2012) and Phillips \& Mesterházy (2015).

Following decades of relative inactivity in Republic of Guinea, in the last seven years there has been a dramatic rise in the publication of new discoveries in other families. Examples are: Brachystephanus

Accepted for publication 1 March 2018. Published online 26 March 2018

1 Royal Botanic Gardens, Kew, Richmond, Surrey, TW9 3AE, UK. e-mail: m.cheek@kew.org

2 Herbier National de Guineé, Université de Gamal Abdel Nasser, Conakry, BP 680, République de Guinée. 

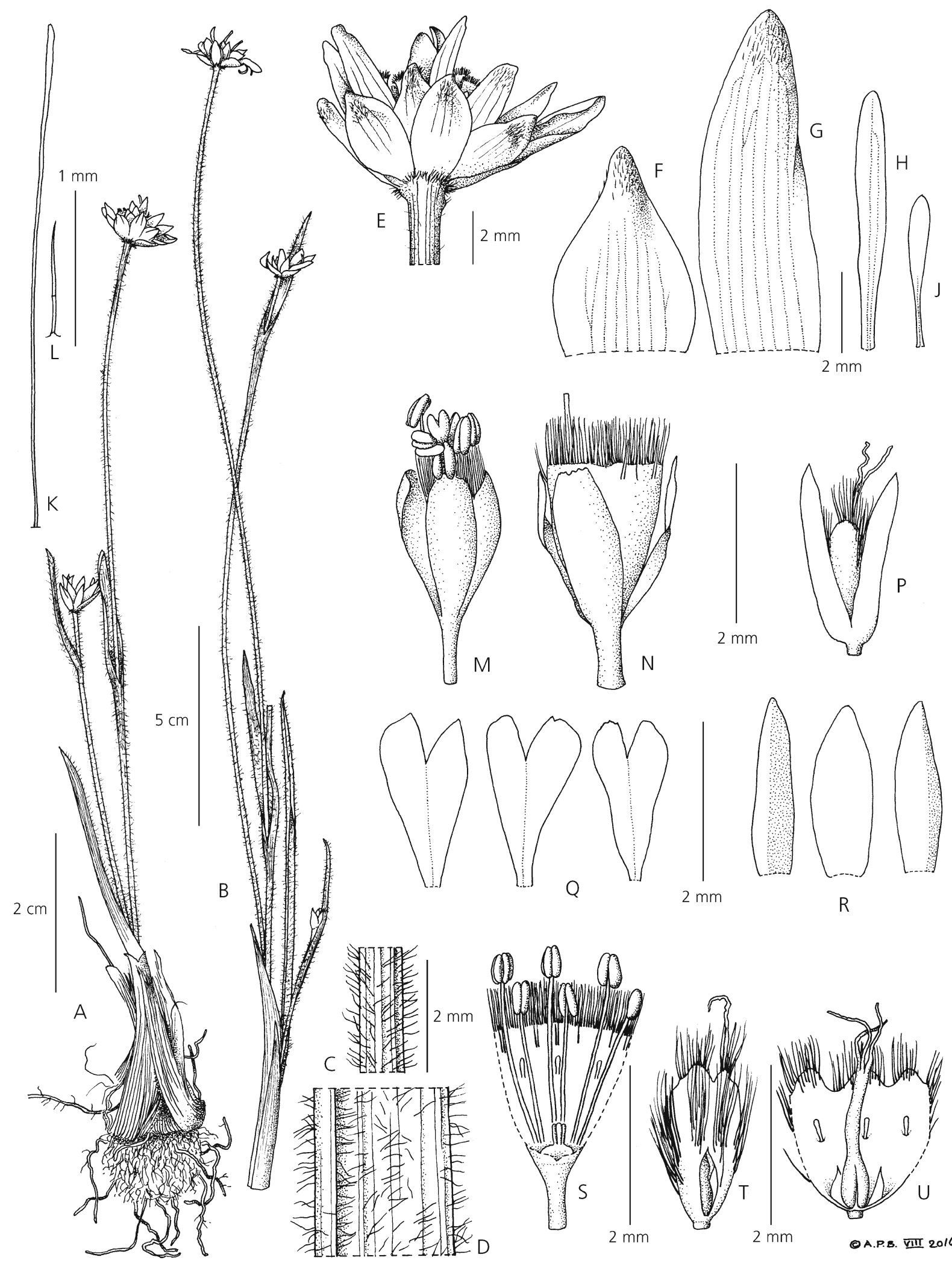

Fig. 1. Mesanthemum tuberosum A habit, small plant showing corm; B habit, tall plant; $C$ scape indumentum; D leaf indumentum, adaxial surface, left margin inrolled; E inflorescence, side-view, hydrated, from A; F outer bract; $\mathrm{G}$ inner bract; $\mathrm{H}$ transitional bract; J floral bract; $\mathrm{K}$ receptacular hair showing slightly clavate distal portion; L detail of 2-celled leaf hair; $\mathrm{M}$ young male flower, lateral view; $\mathrm{N}$ older male flower, lateral view, all anthers fallen; P female flower, lateral view; Q male flower sepals, apices split, midvein present; R female flower sepals, left and right are keeled, central sepal is flat; S male corolla cut and opened out to show stamens (part reconstructed); $T$ female corolla, lateral view; U female corolla cut and opened showing pistil. All from Cheek 18489 (K). DRAWN BY ANDREW BROWN. 
oreacanthus Champl. (Champluvier \& Darbyshire 2009), Eriocaulon cryptocephalum S. M. Phillips \& Mesterházy (2015), Eriosema triformum Burgt (van der Burgt et al. 2012), Gymnosiphon samoritoureanus Cheek (Cheek \& van der Burgt 2010), Inversodicraea pepehabai Cheek (Cheek \& Haba 2016), Napoleonea alata Jongkind (Prance \& Jongkind 2015), Psychotria samoritourei Cheek (Cheek \& Williams 2016), Striga magnibracteata Eb. Fisch. \& I. Darbysh. (Fischer et al. 2011) and Xysmalobium samoritourei Goyder (2009). Just over the border in Mali, Calophyllum africanum Cheek \& Q. Luke (2016) was recently found and in Ivory Coast, Macropodiella cussetiana Cheek (Cheek \& Ameka 2016). Even a new rheophytic genus, Karima Cheek \& Riina has come to light in Guinea (Cheek et al. 2016).

Mesanthemum prescottianum (Bong.) Körn. (Körnicke 1863: 472, t. 60 f. 1); Durand \& Schinz (1895: 504); N. E. Brown (1901: 261); Ruhland (1903: 118); Meikle (1968: 327).

Eriocaulon prescottianum Bong. (Bongard 1831: 635). Type: Sierra Leone ("Brasilia", see below), com. Lindley s.n. (sphalm. Lindly), 1828 (LE lectotype [LE 00001102], designated here; K, isolectotype (K000346197)).

Perennial from a slightly swollen base or with a small corm, flowering towards end of wet season (late July Oct.); sometimes producing small tubers on horizontal stolons; roots dense, tough, tightly attached to substrate. Leaves up to 5 , up to $35 \mathrm{~cm}$ long, $2.6-6 \mathrm{~mm}$ wide, linear or rarely ensiform, flat or lightly folded, outwardly curving when short, pilose especially on upper surface and margins towards base, tip acute. Scapes 1 - 4, 25 - 50 (-67) cm high, slender, pilose. Sheaths pilose, limb acuminate, glabrous or sparsely pilose within. Capitulum shiny white, (17 -) $25-35 \mathrm{~mm}$ wide, flat-topped, greenish crateriform involucre at base. Involucral bracts in several series of increasing length, outer bracts lanceolate-oblong, $2.5-7 \mathrm{~mm}$ long, leathery with thinner margins, pilose with soft dense hairs, acute, inner bracts shiny white, narrowly lanceolate-oblong, radiating ray-like and much exceeding floral disc, 9 - $18 \mathrm{~mm}$ long, thickly papery, outer (lower) surface pubescent, strongly manyveined, veins appearing as furrows on upper surface, acute. Floral bracts fusiform above middle, filiform below, upper part fleshy, glabrous, acute. Receptacle flat, densely villous, hairs usually colourless, occasionally pale brownish-grey, rarely blackish. Flowers 2 $2.5 \mathrm{~mm}$ long. Male flowers: sepals narrowly oblong, free, concave, glabrous, broadly obtuse or minutely denticulate; petal-tube shallowly 3-lobed, upper margin densely villous, pilose inside; anthers dark brown or black. Female flowers: sepals resembling male sepals; petals free below middle, connate above, connate portion with a band of hairs outside from upper margins of free petal-bases, some hairs inside around 3 glands, upper margin shallowly 3-lobed and densely villous. Fig. 2A \& B

DISTRIBUTION. Guinea (Conakry), Ivory Coast, Liberia, Sierra Leone.

SPECIMENS EXAMINED (Three selected from each country where more are available). GUINEA (CONAKRY). Beyla Distr., Simandou Ridge, 8 Nov. 2005, Cheek 12665 (K, HNG); Nzérékoré, Nimba Mts, near pumping station Zougué R., 24 July 2008, Jongkind 8265 (K, WAG); Macenta Prefecture, Ziama Mts, Mt Wokou just S of Macenta, 24 Oct. 2008, Pearce 22 (K, HNG, WAG). IVORY COAST. Mt Tonkoui, Aug. 1954, Schnell 6363 (K, P); Nimba Mts, 10 Aug. 1954, Boughey G.C.18053 (K). LIBERIA. Central Province, Sanokwele Distr., near Sanokwele, 26 Sept. 1947, Baldwin 9516 (K, NY, S, M). SIERRA LEONE. Makeni Hill, 26 Aug. 1951, Jordan 499 (K); Tonkolili Distr., S Sula Mts, NE of Farangbaaya, 12 Sept. 2009, Kanu 6 (FBC, K, SL); $\mathrm{N}$ of Makeni on Kalaba road, 21 Aug. 1967, Morton 4534 (K, SL).

HABITAT. Thin peaty soil over exposed rock with seasonal seepages and in rocky crevices, especially on granite outcrops, often growing with grasses and species of Cyperaceae; 630 - $1600 \mathrm{~m}$.

CONSERVATION STATUS. Mesanthemum prescottianum is here assessed as Least Concern (LC), using the IUCN (2012) Standard. There are about 30 global locations where it is widespread and frequent, and at most of them it is not threatened. The extent of occurrence was measured as $82,953 \mathrm{~km}^{2}$ using Geocat (Bachman et al. 2011). At Tonkolili, Simandou and Nimba it is threatened by exploration for exploitation of iron ore by open-cast mining.

NOTES. Mesanthemum prescottianum has a restricted distribution in the far west of Africa, where it is known only from thin soil over rock, to which it is very tightly affixed. It varies considerably in vigour, capitulum size, hairiness of the involucral bracts, and the colour of the hairs in the capitulum. However, it is always immediately recognisable by its shiny white daisy-like capitula with long, ray-like, usually pointed involucral bracts. The dark anthers of this species and M. tuberosum appear to be unique in the genus, other species having creamy-white or yellowish anthers.

Collections from Sierra Leone and Liberia have capitula with colourless hairs on and around the flowers, so the floral disc is pale. These hairs are light grey-brown in collections seen from Ivory Coast and southern Guinea, giving the floral disc a somewhat darker appearance. A striking variant from the Nimba Mountains in southern Guinea has very large capitula 

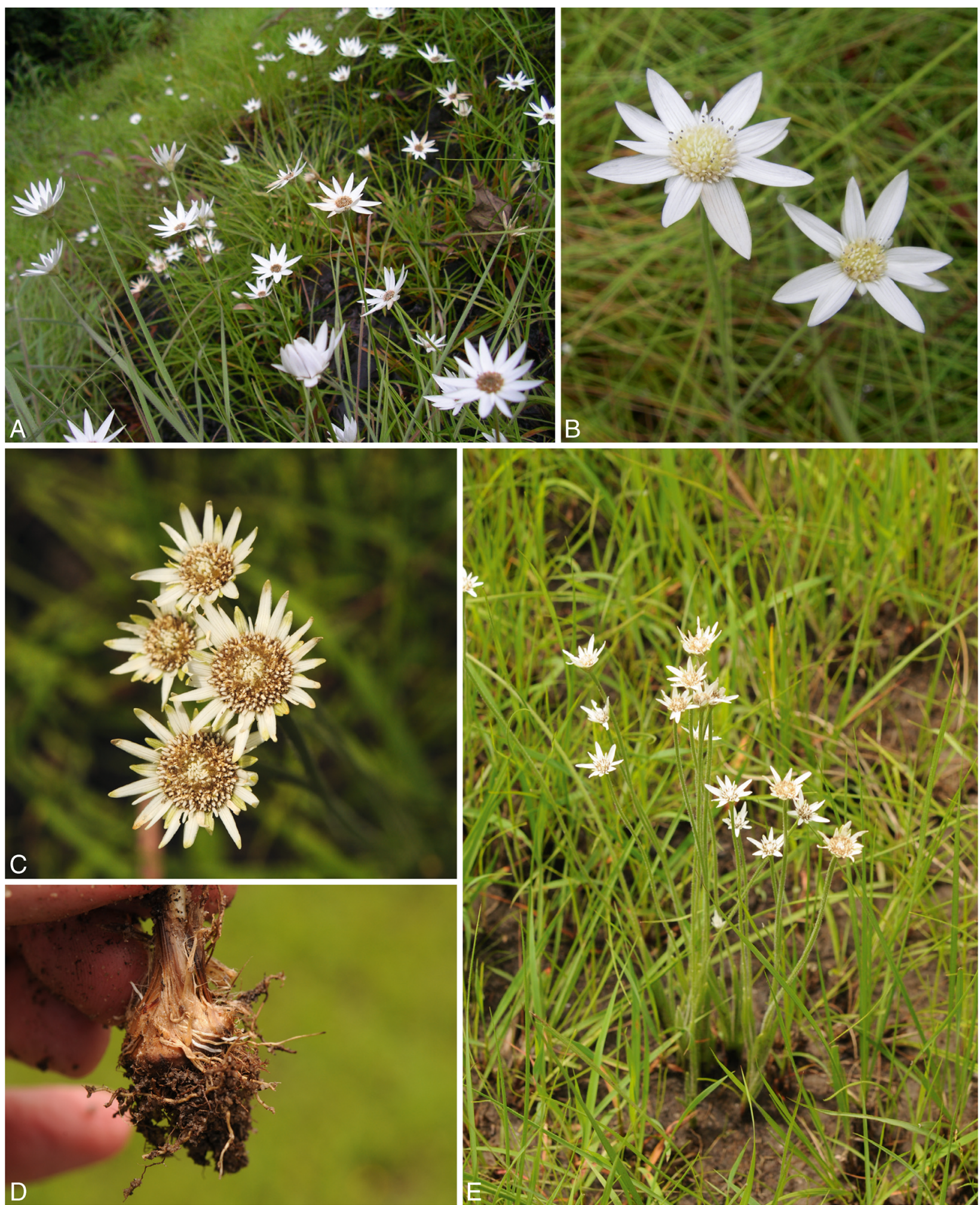

Fig. 2. A, B Mesanthemum prescottianum: A in habitat (Haba 216); B capitulum (Kanu 6). C - E M. tuberosum: C capitulum (Cheek 18489); D corm (Cheek 18489); E in habitat (Cheek 18489);. PHOTOS: A \& B X. VAN DER BURGT, C - E M. CHEEK.

(35 mm wide), almost blackish receptacular hairs and copper-brown sepals, so the capitula have very dark centres (Jongkind 8265 \& 8266).
Mesanthemum prescottianum flowers late in the wet season, reaching peak flowering in August and September and seeding in late October and November, 
the dried capitula persisting on the plant. It typically grows directly on rock in seasonally wet places, never in permanent standing water or marsh.

TYPIFICATION. Bongard was based in St Petersburg (LE). He states in the protologue that he received his specimen from Lindley who had it from the herbarium of D. Prescott. There is a good specimen in LE (LE00001102) with a handwritten label, presumably by Bongard, stating "Eriocaulon prescottianum Bogn! Brasilia, comm. Lindly 1828”. Bongard's protologue also includes a reference to a plate (t. 36) but this was never published, as noted by Körnicke (1863) when he transferred the species to Mesanthemum. One of the plants on the sheet is the basis of t. 36, as indicated by a pencil note.

In the protologue Bongard (1831) gives the provenance of his collection as Rio de Janeiro and the specimen label states "Brasilia". This locality information was repeated by Körnicke who was following Bongard. This appears to be a mistake as Mesanthemum prescottianum is confined to West Africa. Kew also has a specimen of $M$. prescottianum received from Herb. Lindley, stamped "Herb. Benth." and with the handwritten name $M$. radicans. It is probably a duplicate of Bongard's specimen which was sent to Bentham, but has the locality "Sierra Leone". N. E. Brown (1901: 262) remarks that Sierra Leone is much more likely to be the correct origin rather than Brazil. Ruhland (1903) states that other specimens sent out by Lindley have the Sierra Leone locality.

The specimen in St Petersburg is much better than the one at Kew and is the specimen which Bongard used for his protologue. There is no specimen of Mesanthemum prescottianum in either the Cambridge (CGE) or Oxford (OXF) herbaria. The LE duplicate is therefore selected here to be the lectotype, despite the wrong locality information.

Mesanthemum tuberosum Lecomte, Bull. Soc. Bot. France 55: 598 (1908 publ. 1909). Type: Guinea (Conakry), Kouroussa to Timbo, June 1907, Pobéguin 734 (P lectotype [P00443181], designated here).

Perennial from a broad-based corm buried $2 \mathrm{~cm}$ or more deep, flowering at start of wet season (June July); corm well developed, covered in brown fibres. Leaves $1-3,5-26 \mathrm{~cm}$ long, $2.4-10 \mathrm{~mm}$ wide, flat or lightly folded, longer leaves linear, shorter leaves narrowly lanceolate and outwardly curving from sheathing base, pilose with patent hairs especially towards base and on margins, tip hard, subacute. Scapes $1-3$, up to $33 \mathrm{~cm}$ high, densely pilose with patent hairs. Sheaths tightly cylindrical, opening abruptly into flattened acuminate limb. Capitulum dull white, $12-25$ (- 30) $\mathrm{mm}$ wide, flat topped, green or brown crateriform involucre at base. Involucral bracts in several series of increasing length, outer bracts broadly lanceolate, $5-7 \mathrm{~mm}$ long, leathery in lower third, upper part and margins herbaceous, softly pilose, abruptly narrowed above, inner progressively more caudate, becoming broadly linear, extending ray-like beyond floral disc, dull white, fleshy, 3 - 5-veined, obtuse or subacute, innermost shorter and grading into floral bracts, all except outermost subtending flowers. Floral bracts broadly linear to clavate, contracted to filiform base, fleshy, white, glabrous, obtuse or subacute. Receptacle flattened, flowers and slender bases of floral bracts embedded in dense cushion of grey hairs, fleshy white tips of floral bracts protruding above. Flowers $2.5-3.5 \mathrm{~mm}$. Male flowers: sepals elliptic-oblong to obovate, unequally connate at base, concave, glabrous, obtuse; petal-tube shallowly 3-lobed, upper margin densely villous with grey-brown hairs, glabrous inside; anthers dark brown. Female flowers: sepals resembling male sepals; petals free in lower third, connate above, villous in 3 longitudinal bands along seams of upper connate portion, glabrous inside, upper margin shallowly 3-lobed and densely villous with grey-brown hairs. Figs 1, 2C - E

DISTRIBUTION. Guinea (Conakry), Fouta Djalon Highlands, distributed in the highest part of the range in an isosceles triangle which has at its corners the towns of Mali, Mamou and Gaoual. Map. 1.

SPECIMENS EXAMINED. GUINEA (CONAKRY). FOUTA DJALON: Dalaba, $10^{\circ} 37^{\prime} 41.9^{\prime \prime} \mathrm{N} 12^{\circ} 16^{\prime} 46.2^{\prime \prime} \mathrm{W}, 10$ June 2016, Cheek 18489 \& near Forestry House, 21 June 1962, Adames 273 (K); Labe, between Labe and Pita on the road c. $15 \mathrm{~km}$ from Pita, $11^{\circ} 10^{\prime} 47.9^{\prime \prime} \mathrm{N}$ $12^{\circ} 22^{\prime} 51.3^{\prime \prime W}, 12$ June 2016, Konig 30 (K, HNG); 5 km $\mathrm{S}$ of Sériba, $11^{\circ} 4^{\prime} \mathrm{N} 13^{\circ} 1^{\prime} \mathrm{W}, 28$ July 1992, Porembski 44 (K); $40 \mathrm{~km} \mathrm{~W}$ of Labé, $11^{\circ} 2^{\prime} \mathrm{N} 12^{\circ} 4$ 'W, 29 July 1992, Porembski 64; $20 \mathrm{~km} \mathrm{~N}$ of Dalaba, $10^{\circ} 4^{\prime} \mathrm{N} 12^{\circ} 2^{\prime} \mathrm{W}, 30$ July 1992, Porembski 84 (K); $20 \mathrm{~km} \mathrm{~S}$ of Mamou, $10^{\circ} 1$ 'N $12^{\circ} 3^{\prime} \mathrm{W}, 31$ July 1992, Porembski 97 (K); Mamou, Sept. 1954, Schnell 6789 (K); Mali, Sept. 1954, Schnell 7063 (K).

HABITAT. Sandstone bowal with stepped horizontal flats covered in sandy soil; $900-1500 \mathrm{~m}$.

CONSERVATION STATUS. We here assess Mesanthemum tuberosum using the categories and criteria of IUCN (2012) as Vulnerable, VU B2ab(iii), since nine threatbased locations exist (see Map 1), the area of occupancy is $36 \mathrm{~km}^{2}$ using the preferred IUCN 4 $\mathrm{km}^{2}$ cell size, and because threats have been observed at several locations from cattle grazing and trampling to modification of habitat for cultivation (pers. obs. Cheek June 2016). A poster campaign in the Fouta Djalon is intended to raise awareness of the 


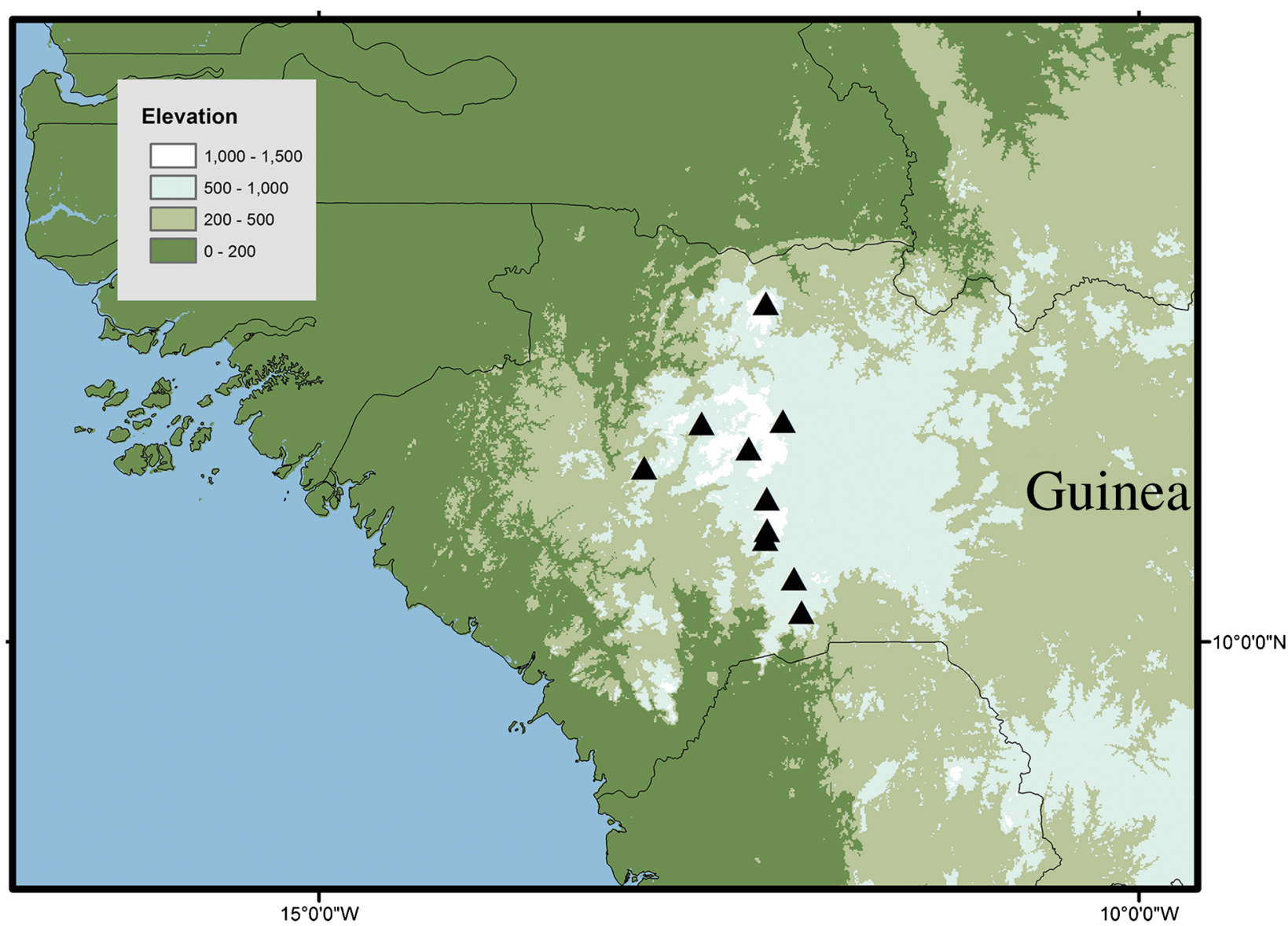

Map 1. Distribution of Mesanthemum tuberosum in Guinea (Conakry).

importance of conserving this threatened rare and endemic species.

NOTES. In dissected specimens the female flowers were few in the axils of the involucral bracts, flowers of the central floral disc being apparently all male.

This taxon appears to be an extreme variant from the Mesathemum prescottianum genepool, confined to the Fouta Djalon area of Guinea. It was described by Lecomte as a new species $M$. tuberosum, but sunk into synonymy by later authors. It differs from
M. prescottianum by the characters set out in Table 1 below. It also occupies a different habitat, which reinforces the decision here to recognise it again at specific rank.

TYPIFICATION. Lecomte (1909) cites three specimens in his protologue, all from the Fouta Djalon upland in Guinea (Conakry): Pobéguin 734 (Kouroussa to Timbo); Caille in Chevalier 15038 (Bilima); Chevalier 18389 (between Timbo and Ditinn). The specimen Pobéguin 734 [P00443181] is labelled as holotype. It is

Table 1. Comparison of the main differences between Mesanthemum prescottianum and M. tuberosum.

\begin{tabular}{|c|c|c|}
\hline & Mesanthemum prescottianum & Mesanthemum tuberosum \\
\hline Habitat & $\begin{array}{l}\text { rocky outcrops with seeping surface water } \\
\text { in wet season }\end{array}$ & $\begin{array}{l}\text { sandy flats overlying impervious rock, damp } \\
\text { in wet season }\end{array}$ \\
\hline Flowering season & mid - late wet season late July - Oct. & early wet season June - July \\
\hline Base of culm & $\begin{array}{l}\text { slender, } 2-3 \mathrm{~mm} \text { thick, tightly attached } \\
\text { to rock by dense network of tough roots }\end{array}$ & $\begin{array}{l}\text { stout, c. } 10 \mathrm{~mm} \text { thick, covered in brown fibres, } \\
\text { roots not anchored to rock }\end{array}$ \\
\hline $\begin{array}{l}\text { Vegetative } \\
\text { reproduction }\end{array}$ & Small white tubers produced on horizontal stolons & Stolons not seen, rosette sometimes dividing \\
\hline Capitulum & shiny white longest involucral bracts acute & dull white longest involucral bracts obtuse \\
\hline
\end{tabular}


a good specimen including a label with collection details and a capsule with dissections. It is therefore selected here as lectotype. A second sheet of Pobéguin 734 [P00443180] is an isolectotype.

\section{Acknowledgements}

The third author's fieldwork costs for this paper were supported by the Darwin initiative DEFRA project 23-002 "Tropical Important Plant Areas of Guinea". Charlotte Couch, Natalie Konig and Fatoumata Fofana supported the fieldwork that led to the rediscovery of Mesanthemem tuberosum. The curators of the herbaria in Cambridge (CGE) and Oxford (OXF) are thanked for searching for possible material of $M$. prescottianum originating from Prescott's herbarium. George Gosline produced the map. Saba Rokni generated the Geocat files that allowed calculations for the IUCN assessments.

Open Access This article is distributed under the terms of the Creative Commons Attribution 4.0 International License (http://creativecommons.org/ licenses/by/4.0/), which permits unrestricted use, distribution, and reproduction in any medium, provided you give appropriate credit to the original author(s) and the source, provide a link to the Creative Commons license, and indicate if changes were made.

\section{References}

Bachman, S., Moat, J., Hill, A. V., De la Torre, J. \& Scott, B. (2011). Supporting Red List threat assessments with GeoCAT, a geospatial conservation assessment tool. Zookeys 150: 117 - 126.

Bongard, M. (1831). Essai monographique sur les espèces d'Ériocaulon du Brésil. Mém. Acad. Imp. Sci. St.-Pétersbourg, Sér. 6, Sci Math 1: 601 - 655.

Brown, N. E. (1901). Eriocaulaceae. In: W. ThiseltonDyer (ed.), Flora of Tropical Africa Vol. 8: 230 - 264. Lovell Reeve \& Co., London.

van der Burgt, X. M., Haba, P. K., Haba, P. M. \& Goman, A. S. (2012). Eriosema triformum (Leguminosae: Papilionoideae), a new unifoliolate species from Guinea, West Africa. Kew Bull. 67 (2): 263 - 271. https://doi.org/10.1007/s12225-012-9357-5

Champluvier, D. \& Darbyshire, I. (2009). A revision of the genera Brachystephanus and Oreacanthus (Acanthaceae) in tropical Africa. Syst. Geogr. Pl. 79 (2): 115 - 192 .

Cheek, M. \& Ameka, G. (2016). Macropodiella cussetiana (Podostemaceae) a new species from Côte d'Ivoire. Kew Bull. 71: 21. https://doi.org/10.1007/S12225016-9634-9.

\& van der Burgt, X. (2010). Gymnosiphon samoritoureanus (Burmanniaceae) a new species from Guinea, with new records of other achlorophyllous heteromycotrophs. Kew Bull. 65: 83 - 88. https://doi.org/10.1007/s12225-010-9180-9

, Challen, G., Lebbie, A., Banks, H., Barberá, P. \& Riina, R. (2016). Discovering Karima (Euphorbiaceae) a New Crotonoid Genus from West Tropical Africa Long Hidden within Croton. PLOS ONE. https://doi.org/10.1371/ journal.pone.0152110

\& Haba, P. (2016). Inversodicraea Engl. resurrected and I. pepehabai sp. nov. (Podostemaceae), a submontane forest species from the Republic of Guinea. Kew Bull. 71: 55. https://doi.org/10.1007/ S12225-016-9673-2

\& Luke, Q. (2016). Calophyllum (Clusiaceae Guttiferae) in Africa. Kew Bull. 71: 20. https:// doi.org/10.1007/S12225-016-9637-6

\& Williams, T. (2016). Psychotria samoritourei (Rubiaceae), a new liana species from Loma-Man in Upper Guinea, West Africa. Kew Bull. 71: 19. https://doi.org/10.1007/S12225-016-9638-5

Darbyshire, I. (continuously updated). Tropical Important Plant Areas. http://science.kew.org/ strategic-output/tropical-important-plant-areas

Anderson, S., Asatryan, A., Byfield, A., Cheek, M., Clubbe, C., Ghrabi, Z., Harris, T., Heatubun, C. D., Kalema, J., Magassouba, S., McCarthy, B., Milliken, W., Montmollin, B. de, Nic Lughadha, E., Onana, J. M., Sa1dou, D., Sarbu, A., Shrestha, K. \& Radford, E. A. (2017). Important Plant Areas: revised selection criteria for a global approach to plant conservation. Biodivers. Conserv. 26: 1767 1800. https://doi.org/10.1007/s10531-017-1336-6.

Durand, T. \& Schinz, H. (1895). Conspectus Florae Africae 5. Jardin Botanique de l'Etat, Bruxelles, Berlin.

Fischer, E., Darbyshire, I. \& Cheek, M. (2011). Striga magnibracteata (Orobanchaceae) a new species from Guinée and Mali. Kew Bull. 66: 441 - 445. https://doi.org/10.1007/s12225-0119296-6

Goyder, D. J. (2009). Xysmalobium samoritourei (Apocynaceae: Asclepiadoideae), a new species from the Guinea Highlands of West Africa. Kew Bull. 63: 473 - 475. https://doi.org/10.1007/ s12225-008-9059-1

Jacques-Félix, H. (1947). Le genre Mesanthemum (Eriocaulaceae). Bull. Soc. Bot. France 94: 143 151.

IUCN (2012). IUCN Red List Categories and Criteria: Version 3.1. Second edition. IUCN, Gland and Cambridge.

Körnicke, F. (1863). Eriocaulaceae. In: C. F. Ph. von Martius \& A. W. Eichler (eds), Flora Brasiliensis, Vol. 3 (1): 274 - 507. Typographia regia, Monachii.

Lecomte, H. (1909). Eriocaulacées d'Afrique. Bull. Soc. Bot. France 55: 594 - 602. 
Meikle, R. D. (1968). Eriocaulaceae. In: F. N. Hepper (ed.), Flora of West Tropical Africa, Ed. 2, 3: 57 C67. Crown Agents, London.

Phillips, S. M. (2010). Eriocaulaceae. In: J. R. Timberlake \& E. S. Martins (eds), Flora Zambesiaca, 13 (4): 1 - 151. Royal Botanic Gardens, Kew.

(2011). Eriocaulaceae. In: Flore du Cameroun 38: 1 -

35. Ministry of Scientific Research \& Innovation, Cameroon.

\& van der Burgt X. M. (2012). Two new species of Eriocaulon (Eriocaulaceae) from Sierra Leone. Kew Bull. 67: 273 - 280.
\& Mesterházy, A. (2015). Revision of small ephemeral species of Eriocaulon (Eriocaulaceae) in West Africa with long involucral bracts. Kew Bull. 70: 5 (17 pp). https://doi.org/10.1007/S12225-0149557-2

Prance, G. T. \& Jongkind, C. C. H. (2015). A revision of African Lecythidaceae. Kew Bull. 70: 6. https://doi.org/10.1007/s12225-0149547-4.

Ruhland, W. (1903). Eriocaulaceae. In: A. Engler (ed.), Das Pflanzenreich Vol. 13: 1 - 294 (IV - 30), Wilhelm Engelmann, Leipzig. 